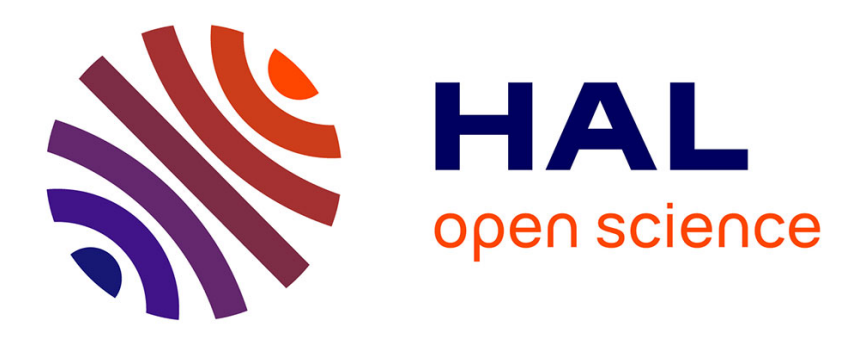

\title{
The orientation of the plan of Novaesium, a Roman fort on the Rhine
}

Amelia Carolina Sparavigna

\section{To cite this version:}

Amelia Carolina Sparavigna. The orientation of the plan of Novaesium, a Roman fort on the Rhine. 2019. hal-02139989

\author{
HAL Id: hal-02139989 \\ https://hal.science/hal-02139989
}

Preprint submitted on 26 May 2019

HAL is a multi-disciplinary open access archive for the deposit and dissemination of scientific research documents, whether they are published or not. The documents may come from teaching and research institutions in France or abroad, or from public or private research centers.
L'archive ouverte pluridisciplinaire HAL, est destinée au dépôt et à la diffusion de documents scientifiques de niveau recherche, publiés ou non, émanant des établissements d'enseignement et de recherche français ou étrangers, des laboratoires publics ou privés. 


\title{
The orientation of the plan of Novaesium, a Roman fort on the Rhine
}

\author{
Amelia Carolina Sparavigna \\ Dipartimento di Scienza Applicata e Tecnologia, Politecnico di Torino, Torino, Italy
}

\begin{abstract}
Novaesium was a Roman fort on the Rhine, a fort which served for the campaigns of Augustus and Drusus against Germans. The plan is the standard one of the Roman camps. Here we discuss its orientation. It has its decumanus having, as far as we can see from archaeological surveys, an azimuth of about 118 degrees. The fort has a perfect orientation "secundum naturam". In the case that this castrum were oriented "secundum coelum", that is in the direction of the sunrise on the day of its foundation, it could had been founded on November 13 or February 1 (Julian dates). This second date is interesting, because it is coincident to the historical date of 30 January, the birthday of Drusus’ mother and Augusts’ wife, Livia.
\end{abstract}

Keywords: Archaeoastronomy.

Writte 22 May 2019. DOI: 10.5281/zenodo.3168183

After the Caesar's Gallic Wars, Rome considered important to establish a better control of the Lower Rhine. A local government and a network of roads were established, in order of securing and developing the areas conquered by Caesar. A further expansionist policy was not under consideration [1]. However the region was subjected to increasing and prolonged attacks by Germanic tribes, which culminated in the so-called Clades Lolliana. The Roman governor Marcus Lollius was defeated by united forces of Sicambri, Tencteri and Usipetes. The Clades, in 17 or 16 $\mathrm{BC}$, changed the policy. In $16 \mathrm{BC}$, Augustus went in Gaul in order to settle, once for all, this Germanic problem. He spent three years in Gaul. In this period the Rhine line lost its formerly defensive character and became an offensive base against the Germanic areas, east of the river. The troops, which had been freed after the Alpine campaigns, were relocated to the Rhine, and the legion camps of Noviomagus at Nijmegen and Vetera at Xanten were built. As Augustus in 13 BC returned to Rome, he gave the supreme command to his stepson Drusus ${ }^{1}$. The large-scale offensive against the Germans, in the years 12-9 BC, took the name of Drusus Offensive.

Novaesium, today Neuss, probably served as a base for the campaigns on the east bank of the Rhine. Drusus led a total of four campaigns there, during which the main activities shifted into the area ofChatti. After his early death, the campaigns were continued by Tiberius (9-6 BC), Lucius Domitius Ahenobarbus (around the year 3 BC), Marcus Vinicius (at the turn of the century) and from the year $4 \mathrm{AD}$ again by Tiberius [1].

1 Nero Claudius Drusus Germanicus (38 BC - summer of 9 BC), was a Roman politician and military commander. He was the son of Livia Drusilla and the legal stepson of her second husband, the Emperor Augustus. He was also brother of the Emperor Tiberius, father to both the Emperor Claudius and general Germanicus, paternal grandfather of the Emperor Caligula, and maternal great-grandfather of the Emperor Nero. 
In [2], we read that Novaesium was, together with Nijmegen, the oldest military base in Germania Inferior, founded by Drusus before 16 BC. It was built on a natural terrace that was protected in the south by a little river, the Erft. Launching his campaigns from Nijmegen and Neuss, Drusus conquered the valley of the Lippe on the east bank of the Rhine. After a couple of years, Nijmegen and Neuss were abandoned, because the army was transferred to Oberaden. In [3] we find Novaesium founded in 16 BC. In it.wikipedia we can find a detailed discussion of Novaesium too.

Let us consider the position of the fort, as we can see from images given in arachne.unikoeln.de/arachne/index.php (8003151: Legions lager Novaesium, sog. Koenenlager Neuss (RheinKreis)) and in Wikipedia. We can prepare the Fig.1.
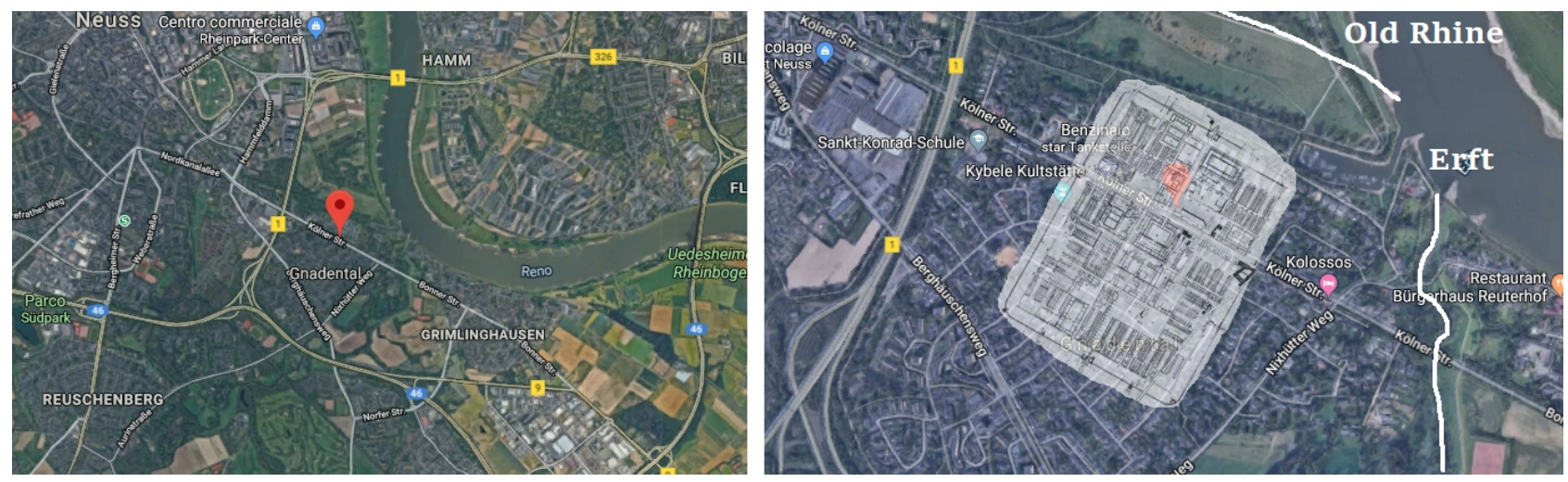

Figure 1. Location of the fort.

In the Figure 1 we can see the location of the fort in Gnadental. On the right, the plan of the fort is added to the satellite image. The main axis of the fort, the decumanus, is the Kölner Strasse. At the time, the Rhine had a different riverbed. River Erft was close to the fort. Probably the water for the fort was obtained from this river.

Usually, the decumanus of a Roman city, castrum (military camp), or colonia, is defined as an eastwest-oriented road [4,5]. However, this is not literally true. The orientation of the decumanus, which is also giving the orientation of the planning of the settlement, was mainly fitting the local environment. Besides this orientation, which is defined "secundum naturam", the axis of a Roman settlement could have been determined by the local presence of a main road [6]. For instance, in the case of Novaesium, the decumanus, which is today the Kölner Strasse, was a part of a Roman road that was running parallel to the old riverbed of the Rhine.

In any case, reasons exist for the supposition of an east-west orientation of the decumani. The supposition is coming from the fact that in the Latin literature it is mentioned the alignment of the main axis of Roman settlements along the sunrise direction on the day of foundation [7]. This orientation is "secundum coelum", that is, according to the Heavens. Then, to complete our discussion on the decumanus of Novaesium, we have to determine if an orientation to the sunrise is possible. For this reason, let us determine its azimuth, from true North. Using a map from arachne.uni-koeln.de/arachne/index.php, we find a value of $118.2^{\circ}$. We can compare it to the sunrise azimuth on days of $17 \mathrm{BC}$ and $16 \mathrm{BC}$. To have the value of the sunrise azimuth we use Stellarium software.

Let us imagine that the decumanus was oriented towards the center of the rising sun. It means that, in the case of a flat horizon - like at Novaesium - and for a standard atmospheric refraction, the center of the sun was at an altitude of $-0^{\circ} 36^{\prime}$ (see detail of the method in [8]).

We find the following azimuths given in the Table 1. 


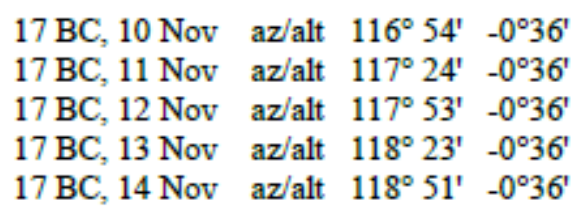

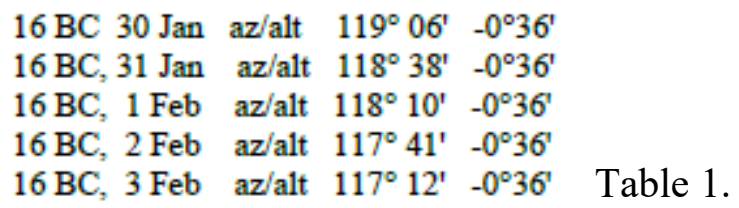

From the Table, we have two days for the foundation of Novaesium, 13 November $17 \mathrm{BC}$ or 1 February $16 \mathrm{BC}$. Let us note that the dates are given according to the Julian dates of Stellarium. These dates are different from those of the Julian Calendar of the time. As discussed in [9], we have some differences. To the dates of the Julian Calendar from (historical) 1 March $17 \mathrm{BC}$ to 28 February $16 \mathrm{BC}$, we have to add 2 to obtain the Julian date. It means that, to the dates of the Table 1 , we have to subtract 2. Therefore 13 November $17 \mathrm{BC}$ was the historical 11 November $17 \mathrm{BC}$ and 1 February $16 \mathrm{BC}$ was the historical 30 January $16 \mathrm{BC}$. This last date (30 January) is particularly interesting. This is the birthday of Livia, the mother of Drusus.

Of course, the orientation of Novaesium "secundum naturam" is the one which seems more probable. However, the possibility exists that Drusus oriented the settlement, founding it on the day of his mother's birthday.

\section{References}

[1] https://de.wikipedia.org/wiki/Novaesium

[2] https://www.livius.org/articles/place/novaesium-neuss/

[3] https://en.wikipedia.org/wiki/Neuss\#Ancient_Rome

[4] https://en.wikipedia.org/wiki/Decumanus_Maximus

[5] John E. Stambaugh (1 May 1988). The Ancient Roman City. JHU Press. pp. 283-. ISBN 978-08018-3692-3.

[6] CENTURIAZIONE, di F. Castagnoli - Enciclopedia dell' Arte Antica (1959)

[7] Sparavigna, Amelia Carolina, Solstices at the Hardknott Roman Fort (December 17, 2014).

PHILICA Article number 442. Available at SSRN: https://ssrn.com/abstract=2745184

[8] Sparavigna, Amelia Carolina. (2019, May 1). Archaeoastronomical analysis of the Roman Colonia Marciana Ulpia Traiana Thamugadi (Timgad), founded at the sunrise of Trajan's Birthday. Zenodo. http://doi.org/10.5281/zenodo.2656658

[9] Sparavigna, Amelia Carolina. (2019, May 16). The first Calends of the Julian Calendar. Zenodo. http://doi.org/10.5281/zenodo.2860135 